\title{
Epiblast Embryo Stem Cells Give Origin to Adult Pluripotent Cell Populations: Primordial Germ Cell, Pericytic and Haematopoyetic Stem Cells. A Review
}

\author{
Las Células Madre del Epiblasto dan Origen a Poblaciones de Células Pluripotentes Adultas: \\ Células Germinales Primordiales, Células Madre Pericíticas y Hematopoyéticas. Revisión
}

*Montiel-Eulefi, E.; ${ }^{* *}$ Sánchez, R.; ${ }^{* * * *}$ Rojas, M. \& ${ }^{* * * *}$ Bustos-Obregón, E.

MONTIEL-EULEFI, E.; SÁNCHEZ, R.; ROJAS, M. \& BUSTOS-OBREGÓN, E. Epiblast embryo stem cells give origin to adult pluripotent cell populations: primordial germ cell, pericytic, and haematopoyetic stem cells: A Review. Int. J. Morphol., 27(4):13251333, 2009.

SUMMARY: Adult stem cells are great promise to the future of regenerative therapy, and understanding of its embryonic origin permit the discrimination of stem cell sources. Embryonic stem cells derived from inner cell mass of blastocyst originate the primordial germ cells, and pericyte stem cell associated to vessels endothelium in yolk sac. Currently, it is being proposed that embryonic primordial germ cell could originate hematopoietic stem cells based on the detection of germ cell markers (SSEA-1/TEC-1, Oct-4 and Nanog) in stem cell harvested from fetal liver and bone marrow. However, different experimental evidence points at two separate differentiation routes toward primordial germ cells, and hematopoietic stem cell with the same embryonic origin. The expression of undifferentiated stem cell markers in umbilical cord and placental vessels, such CD34, CXCR4, c-kit and OCT4 demonstrates the intimate relation between pericyte stem cells, endothelium, haematopoiesis, and primordial germ cells, which all originate from embryonic stem cell from the inner cell mass epiblast.

KEY WORDS: Stem cell origin; Primordial gem cell; Perycitic stem cell; Haemangioblast.

\section{STATE OF THE ART}

Embryonic stem cells (SC) originate all the blood cells in the form of haematopoietic stem cells (HSC) and any one of the 220 types of cells in the body, thus making it possible to replace or reconstruct part of an organ affected by pathology. This means that in medicine, cell therapy can repair the lost functions of tissues and organs by transplanting living cells in to an organism and improving pathologies such as myocardial infarction (MI), bone marrow (BM) transplants, regeneration of burnt skin and other pathologies (Moreno et al., 2003). The presence of HSC in umbilical cord blood (UCB) was first demonstrated in 1974 and ten years later its differentiation in BM was described. It is now known that the percentage of CD34+ HSC cells in cord blood decreases with gestational age; for example, at 17 weeks' gestation, CD34+ cells form a population of $11 \%$ of all mononuclear cells, whereas at week 38 , they are only $1 \%$ of the total population of mononuclear cells. Similarly, it is known that the HSC circulate in a newborn up to 24 hours after birth (Rodriguez et al., 2006). Harvesting HSC from UCB has ample technical advantages over HSC harvested from BM, given their high degree of undifferentiation, low cost, facility for cryopreservation and great plasticity. Even so, the amount of HSC collected is limited because it can only be used directly in the BM transplants of pediatric patients and only with difficulty in adult patients (Smythe $e t$ al., 2007). In order to overcome this disadvantage, studies are being developed for methods that allow the HSC to be expanded in vitro in order to be transplanted to patients who

* Biotechnology of Reproduction Center (CEBIOR), Universidad de la Frontera, Temuco, Chile.

** Departament of Preclinic Sciences, Medicine Faculty, Universidad de la Frontera, Temuco, Chile.

**** Anatomy and Developmental Biology Program. ICBM. Medicine Faculty. Universidad de Chile 
currently cannot benefit from a cord blood transplant because the cell dose is insufficient. The understanding of HSC formation, intimately connected with the endothelium of the vessels during haematopoiesis in the embryonic development as well as in fetal tissues, suggests that it is possible to obtain HSC from vessel stem cells in UC tissues as well as from UCB cells. This implies that the vessel tissue is a source of stem cells can be isolated and used in cell therapy.

Early haematopoiesis in the embryo. The embryonic origin of haematopoiesis is still a matter of controversy. Most studies propose that $\mathrm{HSC}$ are arising from a group of endothelial cells that have the capacity to generate blood cells. Other data suggest that these cells emerge again in the BM from mesenchymal cells. The notion that endothelia and blood cells have a common origin from one primordial cell type or haemangioblast has been matter of study by many generations of scientists (Bollerot et al., 2005; Hirai et al., 2003; Huang et al., 2007). Data obtained by our research group points at direction of the association of embryonic stem cells (ESC) that come from the epiblast of the inner cell mass (ICM) of the embryo and the endothelia of the embryonic vessels in the thophoectoderm. These extraembryonic vessels contribute to development of the placenta, UC and embryonic haematopoiesis. Based on the observation that origin of the primordial germ cells (PGC) lies also in ESC of the epiblast belonging to the ICM of the embryonic disc (ED) (Donovan, 1998; Kucia et al., 2006; Montiel et al., 2001). Kucia et al. (2006, 2007) proposed that the same epiblast PGC would give rise to the haematopoietic cells of the BM and liver by finding PGC markers (SSEA, Oct-4 and Nanog) in stem cells harvested from these organs (Kucia et al., 2006; Kucia et al., 2007; Ratajczak et al., 2007). However, other data indicate that epiblastic stem cells give two distinct derivative routes of the differentiation to PGC (Montiel et al.) and other to vessel associated pericytic stem cells (Crisan et al., 2008). It is beyond question that during early embryogenesis the haematopoietic cells are generated in association with the development of the vascular system. It is for this reason that the first haematopoietic cells have been observed in blood islets in the yolk sac and also there the lineage of endothelial cells (EC) originates from the extraembryonic mesoderm. The haematopoietic SC originating from the yolk sac are transferred during the fetal state, colonizing the liver at a preliminary stage and later the BM (Palis et al., 1999). Nevertheless, the mechanism by which the HSC arrive at the cell niches in the BM has yet to be entirely explained (Huang et al.). The proposal that the cell lineages of the endothelium and the haematopoietic cells develop from a common precursor, the haemangioblast, was initially based on the histological observations of this process (Hirai et al.). Our research group has observed that VASA-RNA-helicase
(Ddx4), a primordial germ cell (PGC) marker (Fujiwara et al., 1994; Toyooka et al., 2003), which also marks the primitive state of the embryonic SC, covers the primitive vessels in pre-implantation stages (6dpc) (Fig. 1B, arrows) (Montiel et al.). These ESC originated from the ICM epiblast (Fig. 1A) of the embryo are the same as those for pluripotent PGC. This suggests the existence of a common population of pluripotent ESC associated with the vessels during embryonic development and the possibility that they are also part of the origin of haematopoietic cells and the primitive endothelium, thereby forming the haemangioblast or an intermediary prior to forming blood SC. These ESC would have an origin in common with the PGC that has already been seen to produce blood cells in vitro (Rich, 1995). The origin of the differentiated blood cells has been observed during embryonic development between days 7-7.5 pc. from the umbilical and vitelline vessels (Samokhvalov et al., 2007; Ueno \& Weissman, 2007) and from the placenta three days after beginning haematopoiesis in the yolk sac (Gekas et al., 2005; Medvinsky \& Dzierzak, 1996) and in the fetus from the region of the aorta-gonads-mesonephros (AGM) (Ueno \& Weissman). Studies with animals reveal that during the migration of the SC that will give rise to PGC towards the genital crests, they change direction, arriving at different tissues (Kucia et al., 2006). On the way, these cells express CXCR4+, a chemokine receptor important in the migration of PGC to the genital crests (Ara et al., 2003; Doitsidou et $a l ., 2002)$ as well as in the migration of tumor cells and tumor invasion (Hwang et al., 2003). Mobilization of the HSC from the BM to systemic blood is due to the disruption of the CXCR4/CXCL12 chemotactic pathway (2003). This receptor is also expressed in UC endothelial cells (Volin et al., 1998), being under the control of the c-Kit receptor or stem cell growth factor receptor (SCF-1) pathway. CXCR4+ is also expressed in BM-SC and fulfills a key role in the implantation of transplanted BM strengthened by SDF1 ligand binding (Peled et al., 1999). Migration of the ESC and PCG that express CXCR4+ to the genital crests occurs via the AGM region, which has been described as one of the places in which HSC have been definitively identified (Kucia et al., 2006; Kucia et al., 2007; Medvinsky \& Dzierzak) suggesting a close relationship between HSC and PGC (Kritzenberger \& Wrobel, 2004).

Haematopoietic Epithelium or Haemangioblast? Finding the presence of haematopoietic differentiation markers (Runx1, CD34) in the aorta endothelium suggests that the definitive haematopoietic cells are generated through an endothelial intermediate with the potential to produce blood cells. This differs from what happens in the yolk sac, where the endothelial cells and haematopoietic cells appear simultaneously. The aorta is formed at least a day before the appearance of haematopoietic islets, suggesting the existence 

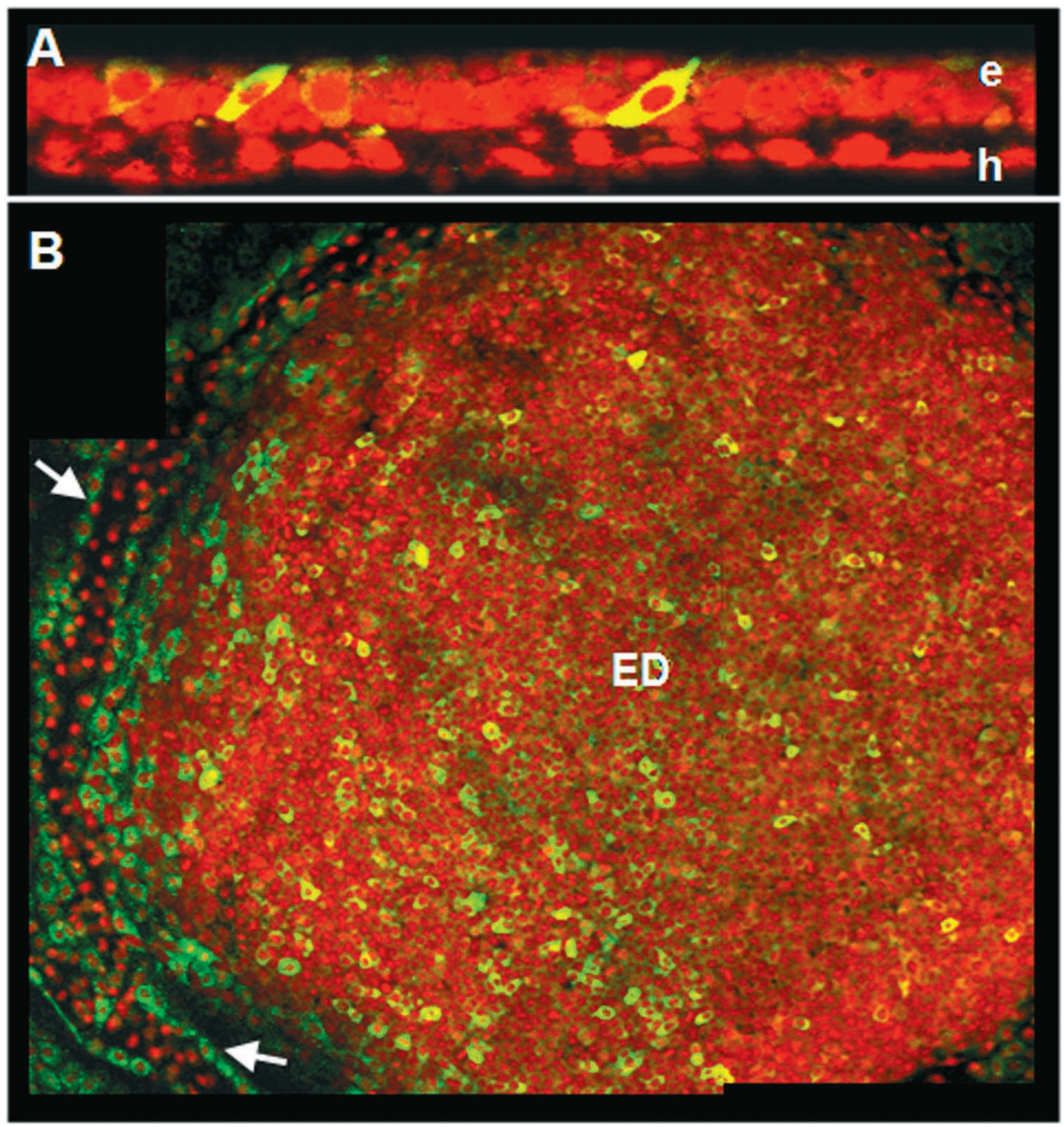

Fig. 1. Expression of VASA/Ddx4 protein in a embryonic disc from a 6dpc rabbit embryo. (A) Orthogonal cut of embryonic disc showing the localization of VASA/Ddx4 a RNA-helicase in the epiblast (e) and absent from the hypoblast (h). (B) Embryonic disc confocal mosaic reconstrucion. Stem cells in the embryonic disc (green/yellow) are recognized by immunocytochemistry staining with antiVASA/Ddx4 antibodies (FITC) (ED). Pericytic stem cells associated to vessels are highlighted in the yolk sac with arrows $(\Rightarrow)$. Cell nucleus were counterstained with propidium iodide (red).

of a specific type of haemangioblast or the presence of a not yet established endothelial intermediary (Samokhvalov et $a l$.). It has been demonstrated that haemangioblast precursors during early gastrulation contain megakaryocyte potential (Tober et al., 2007), determining an endothelial-associated niche (Huang et al.). This raises the question as to whether 
HSC can be generated di novo by other cell types (Bollerot et al.). Wu et al. (2007a) provide an initial demonstration that the endothelial progenitor cell cultures derived from cord blood are able to form blood cells or to undergo a hemogenesis. In vitro culture of endothelial progenitor cells (EPC) collected from the umbilical cord blood revealed a time window in which the developed endothelium has a haematopoietic capacity. This time window occurs after the culture forms a monolayer and CD133-, a SC marker, disappears and the markers VE-cadherin+, vWF+, CD146+ and VEGF-R2 are expressed. At two weeks, cells can be seen that express CD34+/CD133+ and AML-1/Runx1, with this last marker being specific for HSC. As the culture develops, the haematopoietic marker (CD45+) and endothelial marker (VE-cadherin+) appear, indicating the presence of an intermediate endothelial-haematopoietic state, where the transcribed AML-1/Runx 1, e- globin and g- globin are finally expressed in clones derived from the endothelium culture (Wu et al., 2007b).
Histone Deacetylation and DNA Demethylation in Adult Tissues are Responsible for HSC and Pluripotency Gene Expression. Reprogramming adult tissues by inhibiting histone deacetylation and DNA methylation by drugs generate an altered transcriptional active chromatin structure that affect the gene expression. Trichostatin A(TSA) and 5Aza-2'-deoxycytidine (AzaC) induce the hematopoietic potential visualized by CD34 expression, a HSC marker, and pluripotency observed by expression of associated genes as Oct4, Nanog and VASA/Ddx4 an early marker of germinal commitment in reprogramming adult neurosphere cells. Frequently, such genes are epigenetically silenced during development and/or cell differentiation, and TSA/AzaC might reactivate them by removing the epigenetic inhibition (Ruau et al., 2008). The expression of PGC marker VASA/ Ddx4, in short term HSC multi-potent progenitors as RNA helicase is involved in RNA related-processes such as translation initiation, splicing, and nucleosome assembly. Up regulation of VASA/Ddx4 in multi-potent progenitors may
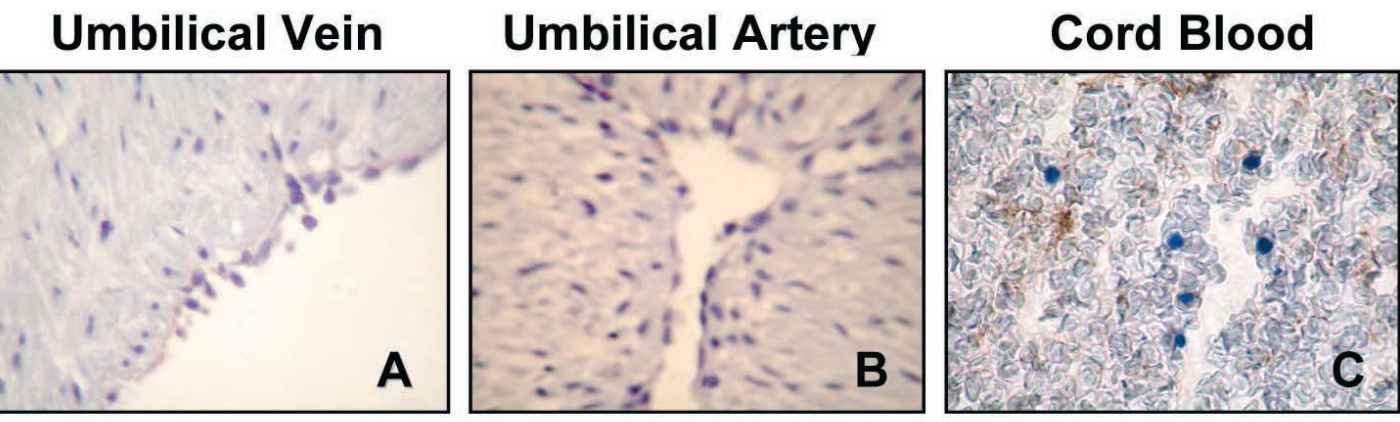

Negative Control
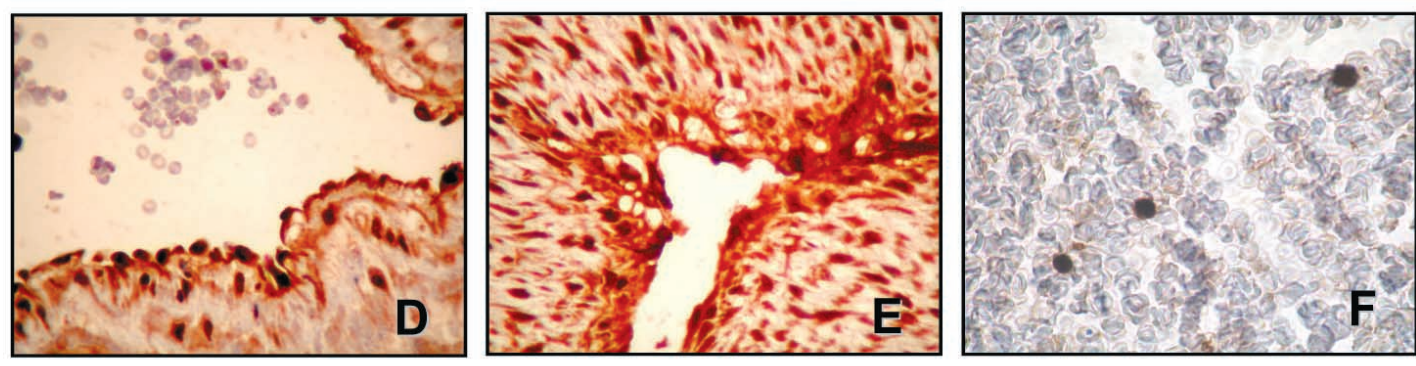

\section{c-Kit/ CD117+}
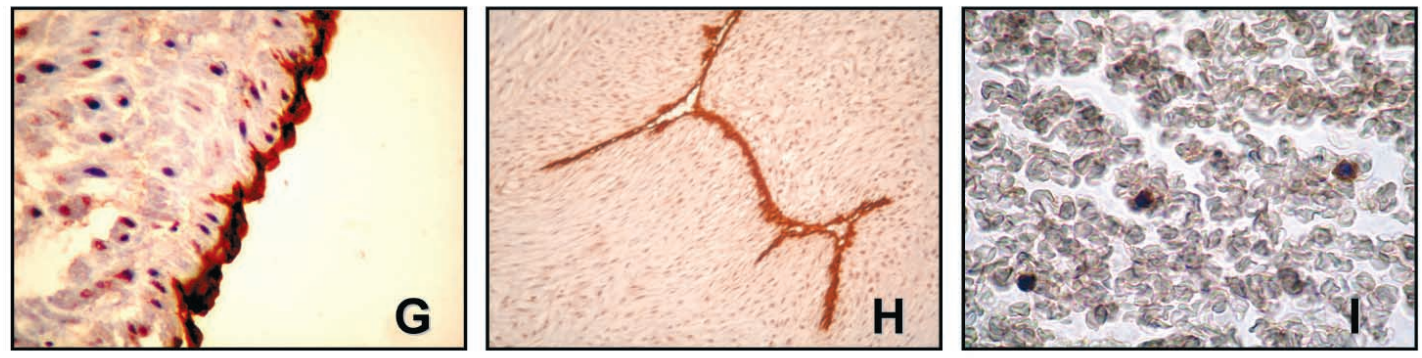

\section{CD34+}

Fig. 2. Immunohistochemistry staining of umbilical cord and blood stem cells. In this microphotograph, a strong marking with CD34+ and c-Kit/CD117+ of the vein endothelium (D and G) and the umbilical artery (E and H) and the cord blood cells (F and I) can be seen. A-C shows the respective IHC negative controls. 
reflect increased or selective translational activity compared to long-term repopulating HSC (Forsberg et al., 2005). Initially VASA/Ddx4 expression was restricted to the germ line; however it recently was shown to be expressed on HSC and to be important in HSC differentiation (Forsberg et al.; Palmqvist et al., 2007; Ruau et al.), noting a common undifferentiated phenotype between HSC and PGC.

Umbilical Cord Endothelium and Perivascular Cells also Express Stem Cell Markers. Umbilical cord blood is one of the main promises in cell therapy for patients with leukemia and other pathologies, resulting in the creation of $\mathrm{SC}$ banks. This source of stem cells has significant limitations to consider, such as the small number of CD34+ and c-Kit+ cells in the UCB (Fig. 2 F, I). The umbilical cord is a young tissue and the endothelium of the vessels is highly capable of being cultivated and expressing HSC markers like CD34+ and CD117 or c-Kit showing an undifferentiated cell state (Yamaguchi et al., 1996) (Fig. 2, D, E, G, H). Furthermore, in culture, the human umbilical vein endothelial cells (HUVEC) also express CD133+, eNOS+, PAI1+, KDR-1+, LOX-1+, TIE-2+, CD31+ and OCT4+ (Nova et al., 2006). This last one is an undifferentiation marker found mainly in ESC and PGC. Nevertheless, the use of UC endothelial cells in cell therapy is work to study. Other cells derived from the cord are pericytic perivascular cells (HuCPVC), with pronounced proliferative and pluripotent activities, giving them the capacity to differentiate in osteogenic tissues and mesenchymal cells (MSC). Genetic microarrays have shown that HuCPVCs express Wnt signaling pathways, which have been involved in the regulation of MSC. The perivascular cells do not express any haematopoietic markers like CD45or CD34-, but they do express SH2+, SH3+, CD90/Thy-1+, CD44+ and remain a homogenous population of fibroblasts expressing a-actin, desmin, vimentin and 3G5 in culture as pericyte markers (Baksh et al., 2007; Sarugaser et al., 2005). Stem cells derived from umbilical cord tissue in therapy. Studies of transplants with endothelial cell lines have shown in a model animal of myocardial infarction (MI) that the improvement in ventricular function is associated mainly with the inflammatory reaction without obtaining tissue regeneration (Merx et al., 2005). This may be because endothelial cell lines differentiate after several passes, reducing their pluripotentiality. Even so, it has not been demonstrated that endothelial cells are transdifferentiated in cardiomyocytes (Welikson et al., 2006). Transplantion of pericytic HuCPVCs into a MI model indicates that these cells can recover cardiac function, representing a substantial source of cells for allogeneic cell therapy from donor to patient (Sarugaser et al.; Wu et al., 2007). On the other hand, it has been observed that mixed cultures of endothelial and pericytic perivascular cells differentiate in vitro into mesenchymal cells and into cardiomyocytes when treated with 5-azacytidine. This demethylating agent has been successfully tested in the differentiation of BM-SC into cardiomyocytes, expressing such cardiac genes as GATA-4, cardiac a-actin, MEF-2 (Burlacu, 2006; Tomita et al., 1999) together with an ultrastructure similar typical sarcomere of cardiomyocytes (Kadivar et al., 2006).

\section{DISCUSSION}

Stem cells are numerous and can be grouped into two main types according to their origin: embryonic stem cells (ESC) and adult stem cells (ASC). Although ESC possess great proliferative capacity that makes them an inexhaustible source (Robinson et al., 2005; Xue et al., 2005), the work with human embryo cells has technical and ethical limitations, resulting in implementation of procedures for harvesting SC from adult tissue. Sources of adult stem cells for therapy vary from the recovery of haematopoietic SC obtained from the patiens own peripheral blood to their isolation from neurons of the olfactory bulb. Given their complexity and the small number of cells obtained, it has become necessary to conduct research into methods that are more efficient in obtaining SC from BM and UC blood, added to the benefit of incorporating the UC tissue cells, which have great potential in cell therapy, as has been described. Recent investigations point to the umbilical cord endothelium relation in forming HSC and EPC (Hirai et al.). These observations combined with the fact that the ESC also give rise to PGC and perycite cells associated with the main vessels demonstrates the possibility of their migration and formation of the beginnings of SC differentiation involving the AGM axis and umbilical cord vessels. This suggests the endothelium as a source of HSC; however, it has not yet been clearly demonstrated that this cell type can develop other types of cells such as cardiomyocytes. More over endothelium functions in tissue regeneration remains unclear (Welikson et al., 2006). Nevertheless, it has been shown that VE-cadherin + cells from the vascular endothelium isolated from embryos and the cord can develop into haematopoietic cells (Hirai et al.). On the other hand, the use of endothelium co-culture/perivascular cells revealed its differentiation capacity to cardiomyocytes (Kadivar et al.). ESC precursors of PGC are the first population of stem cells specified in the embryo at the beginning of gastrulation. These ESC express specific marker as c-Kit, VASA/Ddx4, Oct-4, SSEA-1/TEC1 in early 6 to $6.5 \mathrm{dpc}$ rodent embryo (Montiel et al.; Ratajczak et al.). The developmental deposition of epiblastderived embryonic stem cells and PGC in various organ by its association with vessels forming a pericyte layer could be a possible explanation for the pluripotency of stem cells in adult tissues (Crisan et al.; Kucia et al., 2007). Epiblastic/ 
ICM cells express Ddx4+ in 6 dpc early embryos and develop into two cell populations: the PGC (Kucia et al., 2006) and pericyte vessel-associated stem cells (Crisan et al.). Our observation suggest that epiblast/ICM cells belong to two different populations due to the following reasons: (I) In the extra-embryonic region of the posterior pole of ICM in 7.5 dpc SSEA-1/TEC-1+ and VASA/Ddx4+ cells and populations of cells that express only one of these markers, defined as a different population of ESC and PGC are found in the rabbit embryo. (II) in older embryos VASA/Ddx4+ cells are only expressed in PGC-specified cells until gonade invasion (Montiel et al.). Recent studies have identified BM expressed VASA/Ddx4+, Oct-4+, and other PGC markers and demonstrated that BM cells may also be a source of male and female germ cells. These observations support the concept that during embryonic development, some of the stem cells from the germ lineage may go towards colonizing the fetal liver, and subsequently by the end of the second trimester of gestation together with fetal liver derived HSC move to the BM tissue (Johnson et al., 2005; Nayernia et al., 2006; Ratajczak et al.). Therefore ASC may be characterized as pluripotent embryonary stem cell state. Nevertheless, how the natural mechanisms by ESC arrive at the cell niches in the BM has yet to be entirely explained. The ESC associated to vessels may migrate into adult haematopoietic organs associated to AGM regions by a migration similar to that seen for PGC to gonads. Our defense of the hypothesis: where embryonic vessels associated with pericyte stem cells may derivate to HSC and pluripotential endothelial progenitor cells in a haemangioblast model into adult haematopoietic organs. Possibly arriving to BM via AGM regions like PGC arrive at gonads for developing the germ cells (Fig. 3). Results obtained in our laboratory point to ESC being integrated into trophoblast embryo vessels and giving raise to umbilical cord endothelial and pericyte perivascular cells. This origin would explain these tissues

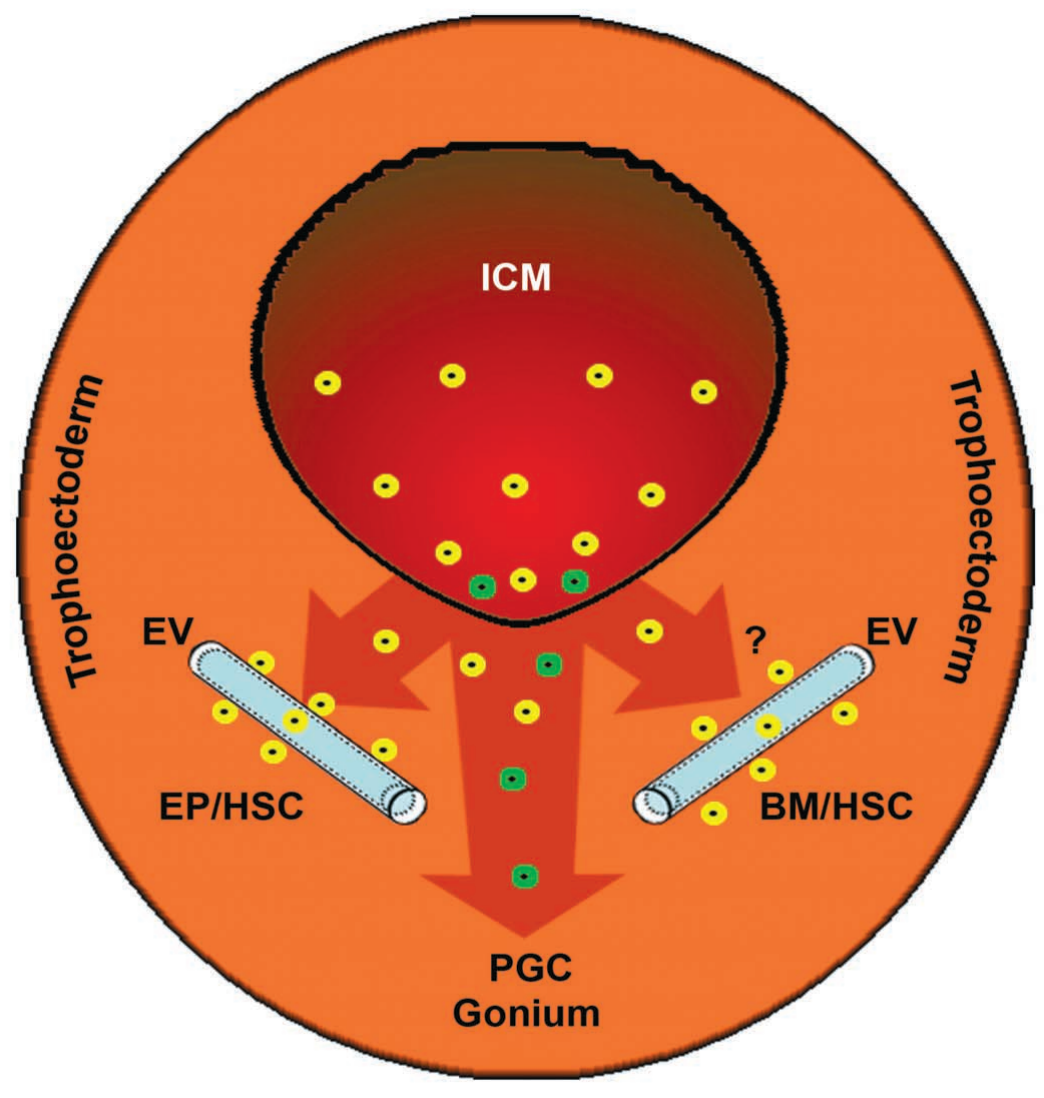

- Embryonary Stem Cell (ESC)

- Primordial Germ Cell (PGC)
Fig. 3. Model of origin of pluripotent tissues from embryonic stem cells. Embryonic stem cells (circles) are appearing early in the development $(\sim 6$ dpc.) in the inner cell mass (ICM) of the embryonic disc. Embryonic stem cells migrate to the trophoectoderm and originate these different pluripotent cell populations such as, primordial germ cells (PGC) (green circles) and embryo vessels (EV) associated with pericytic stem cells. Trophoectoderm vessels originate the placenta and umbilical cord tissues. It suggested that EV-associated stem cells count for expression of undifferentiated markers (c-Kit+, CD34+, and Oct4+) in endothelial cells of the umbilical cord. According to the haemangioblast model, pericytic vessel-associated ESC differentiate into endothelial progenitor (EP) cells and haematopoietic stem cells (HSC). Originating adult haematopoietic organs, and migrate to BM via AGM regions such as $\mathrm{PGC}$ arrive at gonads to develop the germ cell gonium . 
MONTIEL-EULEFI, E.; SÁNCHEZ, R.; ROJAS, M. \& BUSTOS-OBREGÓN, E. Epiblast embryo stem cells give origin to adult pluripotent cell populations: primordial germ cell, pericytic, and haematopoyetic stem cells: A Review. Int. J. Morphol., 27(4):1325-1333, 2009.

maintaining a SC phenotype (CD34+, c-Kit/CD117+) in the umbilical cord. The idea that blood cells could derive from this tissue type, forming haematopoietic islets and HSC during embryonic development (Samokhvalov et al.), reinforces the notion that these cells have great potential in regenerative cell therapy with ASC.

\section{ACKNOWLEDGMENTS}

This work was supported by Chilean Bicentenary Science and Technology Program, CONICYT (PSD32), and DIUFRO, Universidad de La Frontera, Chile (DI08-0036).

MONTIEL-EULEFI, E.; SÁNCHEZ, R.; ROJAS, M. \& BUSTOS-OBREGóN, E. Las células madre del epiblasto dan origen a poblaciones de células pluripotentes adultas: células germinales primordiales, células madre pericíticas y hematopoyéticas. Una Revisión. Int. J. Morphol., 27(4):1325-1333, 2009.

RESUMEN: Las células madre adultas son una gran promesa para el futuro de la terapia regenerativa, y la comprensión de su origen embrionario permite la discriminación de las fuentes de células madre. Las células madre embrionarias derivadas del macizo celular interno del blastocisto originan las células germinales primordiales, y células madre pericíticas asociadas al endotelio de los vasos del saco vitelino. En la actualidad, se propone que las células germinales primordiales embrionarias podrían originar a las células madre hematopoyéticas sobre la base de la detección de marcadores de células germinales (SSEA-1/TEC-1 oct-4 y Nanog) en células madre extraídas de hígado fetal y médula ósea. Sin embargo, diferentes evidencias experimentales apuntan hacia dos vías separadas de diferenciación en células germinales primordiales, y en células madre hematopoyéticas con el mismo origen embrionario. La expresión de marcadores de células madre no diferenciadas en el cordón umbilical y los vasos de la placenta, como CD34, CXCR4, c-kit y OcT4 demuestra la íntima relación entre las células madre pericíticas, el endotelio y las células germinales primordiales, las que se originan en células madre embrionarias a partir del epiblasto del macizo celular interno.

PALABRAS CLAVE: Células madre; Células germinales primordiales; Células madre pericíticas; Hemangioblasto.

\section{REFERENCES}

Ara, T.; Nakamura, Y.; Egawa, T.; Sugiyama, T.; Abe, K.; Kishimoto, T.; Matsui, Y. \& Nagasawa, T. Impaired colonization of the gonads by primordial germ cells in mice lacking a chemokine, stromal cell-derived factor-1 (SDF1). Proc. Natl. Acad. Sci. U S A, 100(186):5319-23, 2003.

Baksh, D.; Yao, R. \& Tuan, R. S. Comparison of proliferative and multilineage differentiation potential of human mesenchymal stem cells derived from umbilical cord and bone marrow. Stem Cells., 25(6):1384-92, 2007.

Bollerot, K.; Pouget, C. \& Jaffredo, T. The embryonic origins of hematopoietic stem cells: a tale of hemangioblast and hemogenic endothelium. APMIS, 113(11-12):790-803, 2005.

Burlacu, A. Can 5-azacytidine convert the adult stem cells into cardiomyocytes? A brief overview. Arch. Physiol. Biochem., 112(4-5):260-4, 2006.

Crisan, M.; Yap, S.; Casteilla, L.; Chen, C. W.; Corselli, M.; Park, T. S.; Andriolo, G.; Sun, B.; Zheng, B.; Zhang, L.; Norotte, C.; Teng, P. N.; Traas, J.; Schugar, R.; Deasy, B. M.; Badylak, S.; Buhring, H. J.; Giacobino, J. P.; Lazzari, L.; Huard, J. \& Péault, B. A perivascular origin for mesenchymal stem cells in multiple human organs. Cell Stem Cell, 3(3):301-13, 2008.
Moreno, C. J. E.; López-Franco, R. \& González-Garza, B. T. Terapia celular: La medicina del futuro. http:// transferencia.mty.itesm.mx/63/63-III.01.html, 2003.

Doitsidou, M.; Reichman-Fried, M.; Stebler, J.; Köprunner, M.; Dörries, J.; Meyer, D.; Esguerra, C. V.; Leung, T. \& Raz, E. Guidance of primordial germ cell migration by the chemokine SDF-1. Cell, 111(5):647-59, 2002.

Donovan, P. J. The germ cell--the mother of all stem cells. Int. J. Dev. Biol., 42(7):1043-50, 1998.

Forsberg, E. C.; Prohaska, S. S.; Katzman, S.; Heffner, G. C.; Stuart, J. M. \& Weissman, I. L. Differential expression of novel potential regulators in hematopoietic stem cells. PLoS Genetics, 1(3):e28, 2005.

Fujiwara, Y.; Komiya, T.; Kawabata, H.; Sato, M.; Fujimoto, H.; Furusawa, M. \& Noce, T. Isolation of a DEAD-family protein gene that encodes a murine homolog of Drosophila vasa and its specific expression in germ cell lineage. Proc. Natl. Acad. Sci. U S A, 91(25):12258-62, 1994.

Gekas, C.; Dieterlen-Lièvre, F.; Orkin, S. H. \& Mikkola, H. $\mathrm{K}$. The placenta is a niche for hematopoietic stem cells. Dev. Cell., 8(3):365-75, 2005. 
Hirai, H.; Ogawa, M.; Suzuki, N.; Yamamoto, M.; Breier, G.; Mazda, O.; Imanishi, J. \& Nishikawa, S. Hemogenic and nonhemogenic endothelium can be distinguished by the activity of fetal liver kinase (Flk)-1 promoter/ enhancer during mouse embryogenesis. Blood, 101(3):886-93, 2003.

Huang, X.; Cho, S. \& Spangrude, G. J. Hematopoietic stem cells: generation and self-renewal. Cell Death Differ., 14(11):1851-9, 2007.

Hwang, J. H.; Chung, H. K.; Kim, D. W.; Hwang, E. S.; Suh, J. M.; Kim, H.; You, K. H.: Kwon, O. Y.; Ro, H. K.; Jo, D. Y. \& Shong, M. CXC chemokine receptor 4 expression and function in human anaplastic thyroid cancer cells. $J$. Clin. Endocrinol. Metab., 88(1):408-16, 2003.

Johnson, J.; Bagley, J.; Skaznik-Wikiel, M.; Lee, H. J.; Adams, G. B.; Niikura, Y.; Tschudy, K. S.; Tilly, J. C.; Cortes, M. L.; Forkert, R.; Spitzer, T.; Iacomini, J.; Scadden, D. T. \& Tilly, J. L. Oocyte generation in adult mammalian ovaries by putative germ cells in bone marrow and peripheral blood. Cell, 122(2):303-15, 2005.

Kadivar, M.; Khatami, S.; Mortazavi, Y.; Shokrgozar, M. A.; Taghikhani, M. \& Soleimani, M. In vitro cardiomyogenic potential of human umbilical veinderived mesenchymal stem cells. Biochem. Biophys. Res. Commun., 340(2):639-47, 2006.

Kritzenberger, M. \& Wrobel, K. H. Histochemical in situ identification of bovine embryonic blood cells reveals differences to the adult haematopoietic system and suggests a close relationship between haematopoietic stem cells and primordial germ cells. Histochem. Cell Biol., 121(4):273-89, 2004.

Kucia, M.; Machalinski, B. \& Ratajczak, M. Z. The developmental deposition of epiblast/germ cell-line derived cells in various organs as a hypothetical explanation of stem cell plasticity? Acta Neurobiol. Exp. (Wars), 66(4):331-41, 2006.

Kucia, M.; Wu, W. \& Ratajczak, M. Z. Bone marrow-derived very small embryonic-like stem cells: Their developmental origin and biological significance. Dev. Dyn., 236(12):3309-20, 2007.

Lévesque, J. P.; Hendy, J.; Takamatsu, Y.; Simmons, P. J. \& Bendall, L. J. Disruption of the CXCR4/CXCL12 chemotactic interaction during hematopoietic stem cell mobilization induced by GCSF or cyclophosphamide. J. Clin. Invest., 111(2):187-96, 2003.
Medvinsky, A. \& Dzierzak, E. Definitive hematopoiesis is autonomously initiated by the AGM region. Cell, 86(6):897-906, 1996.

Merx, M.W.; Zernecke,A.; Liehn, E.A.; Schuh,A.; Skobel, E.; Butzbach, B.; Hanrath, P.; \& Weber, C. Transplantation of human umbilical vein endothelial cells improves left ventricular function in a rat model of myocardial infarction. Basic. Res. Cardiol., 100(3):20816, 2005.

Montiel, E.; Guillomot, M.; Rojas, M.; Bustos-Obregon, E. \& Flechon, J. Primordial germ cell characterization by immunohistochemistry of vasa-homologue protein in preimplantational rabbit embryos. Int. J. Dev. Biol., 45:S141-S2, 2001.

Nayernia, K.; Lee, J. H.; Drusenheimer, N.; Nolte, J.; Wulf, G.; Dressel, R.; Gromoll, J. \& Engel, W. Derivation of male germ cells from bone marrow stem cells. Lab. Invest., 86(7):654-63, 2006.

Nova, E.; Searle, A.; Duran, D.; Vera, J.; Rivas, C. \& Lamperti, L. Culture and characterization of human endothelial progenitor cells isolated from peripheric blood. XX Annual Meeting of Cell Biology Chilean Society, XX:19, 2006.

Palis, J.; Robertson, S.; Kennedy, M.; Wall, C. \& Keller, G. Development of erythroid and myeloid progenitors in the yolk sac and embryo proper of the mouse. Development, 126(22):5073-84, 1999.

Palmqvist, L.; Pineault, N.; Wasslavik, C. \& Humphries, R. K. Candidate genes for expansion and transformation of hematopoietic stem cells by NUP98-HOX fusion genes. PLoS One, 2(1):e768, 2007.

Peled, A.; Petit, I.; Kollet, O.; Magid, M.; Ponomaryov, T.; Byk, T.; Nagler, A.; Ben-Hur, H.; Many, A.; Shultz, L.; Lider, O.; Alon, R.; Zipori, D. \& Lapidot, T. Dependence of human stem cell engraftment and repopulation of NOD/SCID mice on CXCR4. Science, 283(5403):8458, 1999.

Ratajczak, M. Z.; Machalinski, B.; Wojakowski, W.; Ratajczak, J. \& Kucia, M. A hypothesis for an embryonic origin of pluripotent Oct-4(+) stem cells in adult bone marrow and other tissues. Leukemia, 21(5):860-7, 2007.

Rich, I. N. Primordial germ cells are capable of producing cells of the hematopoietic system in vitro. Blood, 86(2):463-72, 1995. 
Robinson, R. B.; Rosen, M. R.; Brink, P. R. \& Cohen, I. S. Letter regarding the article by Xue et al., "Functional integration of electrically active cardiac derivatives from genetically engineered human embryonic stem cells with quiescent recipient ventricular cardiomyocytes". Circulation, 112(6):e82, 2005.

Rodriguez, V. M.; Cuellar, A.; Cuspoca, L. M.; Contreras, C. L.; Mercado, M. \& Gomez, A. Phenotypical determinants of stem cell subpopulations derived from human umbilical cord blood. Biomedica, 26(1):51-60, 2006.

Ruau, D.; Ensenat-Waser, R.; Dinger, T. C.; Vallabhapurapu, D.S.; Rolletschek, A.; Hacker, C.; Hacker, C.; Hieronymus, T.; Wobus, A. M.; Müller, A. M. \& Zenke, M. Pluripotency Associated Genes Are Reactivated by Chromatin-Modifying Agents in Neurosphere Cells. Stem Cells, 26(4):920-6, 2008.

Samokhvalov, I. M.; Samokhvalova, N. I. \& Nishikawa, S. Cell tracing shows the contribution of the yolk sac to adult haematopoiesis. Nature, 446(7139):1056-61, 2007.

Sarugaser, R.; Lickorish, D.; Baksh, D.; Hosseini, M. M. \& Davies, J. E. Human umbilical cord perivascular (HUCPV) cells: a source of mesenchymal progenitors. Stem Cells, 23(2):220-9, 2005.

Smythe, J.; Armitage, S.; McDonald, D.; Pamphilon, D.; Guttridge, M.; Brown, J.; Green, A.; Brown, C.; Warwick, R. M.; Lankester, A.; Fehily, D.; Contreras, M.; Navarrete, C. \& Watt, S. M. Directed sibling cord blood banking for transplantation: the 10-year experience in the national blood service in England. Stem Cells, 25(8):2087-93, 2007.

Tober, J.; Koniski, A.; McGrath, K. E.; Vemishetti, R.; Emerson, R.; de Mesy-Bentley, K. K.; Waugh, R. \& Palis, $\mathrm{J}$. The megakaryocyte lineage originates from hemangioblast precursors and is an integral component both of primitive and of definitive hematopoiesis. Blood, 109(4):1433-41, 2007.

Tomita, S.; Li, R.K.; Weisel, R.D.; Mickle, D.A.; Kim, E.J.; Sakai, T. \& Jia, Z. Q. Autologous transplantation of bone marrow cells improves damaged heart function. Circulation, 100(19):II247-56, 1999.

Toyooka, Y.; Tsunekawa, N.; Akasu, R. \& Noce, T. Embryonic stem cells can form germ cells in vitro. Proc. Natl. Acad. Sci. U S A, 100(20):11457-62, 2003.
Ueno, H. \& Weissman, I. L. Stem cells: blood lines from embryo to adult. Nature, 446(7139):996-7, 2007.

Volin, M. V.; Joseph, L.; Shockley, M. S. \& Davies, P. F. Chemokine receptor CXCR4 expression in endothelium. Biochem. Biophys. Res. Commun., 242(1):46-53, 1998.

Welikson, R. E.; Kaestner, S.; Reinecke, H. \& Hauschka, S. D. Human umbilical vein endothelial cells fuse with cardiomyocytes but do not activate cardiac gene expression. J. Mol. Cell. Cardiol., 40(4):520-8, 2006.

Wu, X.; Lensch, M. W.; Wylie-Sears, J.; Daley, G. Q. \& Bischoff, J. Hemogenic endothelial progenitor cells isolated from human umbilical cord blood. Stem Cells, 25(11):2770-6, 2007a.

Wu, K. H.; Zhou, B.; Mo, X. M.; Cui, B.; Yu, C. T.; Lu, S. H.; Han, Z. C. \& Liu, Y. L. Therapeutic potential of human umbilical cord-derived stem cells in ischemic diseases. Transplant. Proc., 39(5):1620-2, 2007 b.

Xue, T.; Cho, H. C.; Akar, F. G.; Tsang, S. Y.; Jones, S. P.; Marban, E.; Tomaselli, G. F. \& Li, R. A. Functional integration of electrically active cardiac derivatives from genetically engineered human embryonic stem cells with quiescent recipient ventricular cardiomyocytes: insights into the development of cell-based pacemakers. Circulation, 111(177):11-20, 2005.

Yamaguchi, H.; Ishii, E.; Saito, S.; Tashiro, K.; Fujita, I.; Yoshidomi, S.; Ohtubo, M.; Akazawa, K. \& Miyazaki, $\mathrm{S}$. Umbilical vein endothelial cells are an important source of c-kit and stem cell factor which regulate the proliferation of haemopoietic progenitor cells. $\mathrm{Br}$. J. Haematol., 94(4):606-11, 1996.

\section{Correspondence to:}

Enrique Montiel Eulefi, Ph.D. Neuroscience Laboratory, CEBIOR. Universidad de la Frontera

P.O. Box: 54-D. Montevideo 0870.

Temuco, CHILE

Tel.: +56-45-722089

Fax: $+56-45-234326$.

Email: emontiele@gmail.com

Received: 13-10-2009

Accepted: 04-11-2009 
